\title{
Assessment of the Legal Environment in Lao PDR for Chinese Investment in the Hydropower Industry
}

\author{
Saithong Rattana, Dr. Li Lairu \\ International Business School \\ Yunnan University of Finance and Economics \\ Kunming, China \\ 67692019@qq.com
}

\begin{abstract}
The Legal Environment in Laos for Chinese Investment in the Hydropower Industry is the hot matter in the moment. Lao PDR needs to manage its hydropower development to ensure environmental and social sustainability through developing of the legal, institutional and regulatory environment and strengthening of the institutional capacity of the sector, improving knowledge and data management, and developing institutional coordination across the government agencies. This paper will make an introduction to the legal system in Laos concerning foreign investment. And a full-scale of assessment of the legal environment could be made on cases and data in this paper. In conclusion, Laos is becoming open and investmentfriendly. The paper can also act as a discussion awakener, to help and give some guidance to decision makers and actors in the hydropower sector to integrate sustainable development considerations into hydropower development and planning.
\end{abstract}

Key words-Legal Environment; Chinese Investment; Hydropower Industry in Lao PDR

\section{INTRODUCTION}

\section{A. Background and rationale}

\section{1) Trade environment of Laos}

Lao PDR is located in the center of Southeast Asia and shares borders with China in the north, Cambodia in the south, Viet Nam in the east, and Thailand and Myanmar in the west. The country has a total land area of 236,800 square $\mathrm{km}$, on which about 5.6 million people are living. Socioeconomically, Lao PDR is classified as least developed country (LDC) with Gross Domestic Product (GDP) per capita of US\$924 in 2009. Agriculture is an important economic sector, contributing approximately 29.9 percent of GDP in 2009. The sector employs over 70 percent of the country's total labor force [1].

In 1986, Lao PDR adopted a comprehensive reform program called the New Economic Mechanism (NEM) to shift its central economic planning model to a market-oriented one. The program brought about open-door and integration policies in the following years. The open-door and integration policies had significant effects on the livelihood of the Lao people, including their production capacity.
In addition, Lao PDR is working toward its acceptance to the World Trade Organization (WTO). When it becomes a

member of the WTO, it will gain access to foreign markets and opportunities to get more investments and technological advancements, which are important factors in stimulating economic growth and reducing poverty in the long term. However, to get the real benefits of WTO accession, the country has to stimulate its production capacities, enhance productivity, and improve the quality of its products in order to increase its competitiveness in the international market. Laos has bilateral investment agreements with Australia, Burma, Cambodia, China, Cuba, Denmark, France, Germany, India, Indonesia, Japan, Kuwait, Malaysia, Mongolia, Netherlands, North Korea, Pakistan, Philippines, Russia, South Korea, Singapore, Sweden, Switzerland, Thailand, the United Kingdom, the United States and Vietnam. On February 1, 2005 a Bilateral Trade Agreement (BTA) came into force between the U.S. and the Government of Laos. Laos and the United States do not have a bilateral taxation treaty [2].

\section{2) Hydropower Industry of Laos}

Commonly speaking, hydropower has wild range of economical, environmental and social strategic advantages. Hydropower is a significant source of electricity worldwide and will likely continue to grow especially in the developing countries [3], thus it can play an essential role in economical development especially in many developing countries where there are hydropower potentials.

Like many countries, the Lao People's Democratic Republic (Lao PDR) as the least developed country is in fashion of receiving Foreign Direct Investment (FDI) mainly in hydropower sector which comparing by sector from the year of 2000-2010, hydropower sector accounted more than thirty three percents of total FDI (MPI, Laos). Due to Lao' nature and climate provide great opportunities to develop hydropower plants to meet domestic electrification needs and the increase in demand for electric power in the region of South-East Asia. Today, more than 70 hydropower projects are under development, and the electricity sector makes up an important part of the export industry in Laos. Thus it has played an essential role in the rapid economic growth of Lao 
PDR.). Hydropower resource is the most abundant energy resource in Lao PDR. Laos is endowed with vast hydropower potential, making it a major source of renewable energy generation for the country. Over the years, Laos has progressively developed its hydro resources, with the aim of achieving electrification across its territory, while at the same time helping to reduce carbon-based generation throughout the Southeast Asian region by providing clean electricity from hydropower to consumers living beyond its territory.

As the government of Lao PDR set the economic outlook in the year 2020, its vision to the year 2020 is to graduate from the status of being a least developed country and become a sustainable development nation. To achieve such goal of National Development Vision to the year 2020, Lao PDR needs more capitals, technology, and capable human resource, as the Government of Lao PDR lack of these things. Thus, the FDI especially in Mega projects such as hydropower sector and mining sector are the significant contributors for increasing the government's revenue, creating jobs, introducing new market and business system.

\section{3) Chinese Investment in Laos}

China is the largest foreign investor in Laos Following on from recent posts on related issues, the readers may be interested that China has just dislodged Thailand as the largest investor in Laos. Since 2000, Chinese investment has totaled US\$2.9 billion, compared to $\$ 2.6$ billion from Thailand and $\$ 2.2$ billion from Vietnam. China has replaced Thailand as the biggest foreign investor in Laos for the first time in five years, thanks to the Lao government's active promotion of foreign investment in the country. According to the latest report from the Ministry of Planning and Investment's Investment Promotion Department, the value of Chinese investment in Laos has reached about US\$2.9 billion since the government began welcoming foreign investment in 2000. Thailand was the top investor in Laos from 2005 to 2009 before losing the position to China due to a rapid increase in Chinese investment over the first two quarters of this year.

The Chinese government provides considerable foreign aid to Cambodia, Laos and Vietnam, often without any major conditions attached and frequently integrated with cultural exchange and support. While significant compared to other donors, China's ODA is not often linked to the agribusiness, hydropower and mining sectors but mostly includes support for transport; communications; health, education and human resources development; and construction (of sports, culture and government building complexes) sectors. Cambodia is the only country among the three where the Chinese government has earmarked aid for hydropower development projects [4].

Laos and China have enjoyed a good relationship over many years. Leaders from the two countries have cooperated in different development sectors, including assistance with goods trading and investment promotion. Such cooperation and economic promotion plans have pushed strong growth in the trade and investment value of the two countries, with China now the top foreign investor in Laos.

The investment from China is a main factor to boost the economic growth in Laos and generate significant income for the Lao government. In addition, the Chinese investment has contributed to the local development and created a number of jobs for Lao people [5]. The Chinese investment projects are mostly in the mining sector. During the forum, the Lao and Chinese sides also agreed to continue their cooperation on information, especially the selection of the qualified Chinese companies to implement the investment projects in Laos. The Lao side also asked the Chinese side to send the name list of the qualified and experienced Chinese companies to Laos as information for consideration. Dr. Sinlavong Khoudphaythoune, Minister of Planning and Investment, also urged the Chinese investors to improve and upgrade its investment quality to the international standard and to respect the rule, laws and custom of Lao people [6].

Administrator Bilateral Trade 2012, China is one of the biggest import markets in the world. Its key trading partners are the United States of America, Hong Kong, Japan, R.Korea, Germany, and Chinese-Taipei. In 2007, its value of exports and imports reached US $\$ 371.8$ billion. China's main import commodities are machinery and equipment, oil and mineral fuels, plastics, Light Emitting Diode (LED) screens, data processing equipment, optical and medical equipment, organic chemicals, steel, and copper. For Lao PDR, China is the second largest trading partner after Thailand. The GoL and China have set a target to increase bilateral trade value of US\$ 1 billion by 2006-2010. In October 2008, Lao-China trade was worth more than US\$ 348 million. Major exports from Lao PDR to China are mining, agricultural products, handicraft, forestry products, wood and wood products and furniture. Lao PDR has market access opportunities to Chinese market in several ways.

\section{B. Investment Policy Effect On FDI In Hydropower Sector}

In general, Foreign Direct Investment (FDI) has come into sight to be broadly recognized over the past decade in many countries as it contributes growth and the development. It can bring capital, technology transferring, job creation and management knows how to the host countries. Thus it had been known as the essential tool for economic development particularly in developing countries, where there are rich in natural resources and labor forces.

The Lao government will increase efforts to encourage foreign investment in Laos over the next five years to ensure that annual GDP growth stays above 8 percent. It is hoped that this will enable Laos to remove itself from the UN list of least-developed nations by 2020. The Lao government revised the Investment Promotion Law last year, aiming to improve the investment consideration process and offer a number of investment incentives including tax exemptions and reductions for companies investing in rural areas. The revised law also allows the government to use land use rights as an incentive to attract foreign investors to Laos. According to Article 58 of the law, any foreign investors who have an investment project with registered funds of more than US\$500,000 can purchase land use rights for real estate development from the government in an allocated area. Policy makers believe that allowing foreign investors to own property in the country will make them feel confident about investing in Laos. Not many countries allow foreigners to 
own property as the extra competition can lead to a sharp increase in land prices [7].

Runckel \& Associates, Inc, (2015) FDI has contributed to the development of the Lao economy during the transition of the country into a market driven economy [8]. FDI has benefited the country in terms of its contribution to the socioeconomic development, foreign exchange earnings, technological advantages, increased gross domestic product, and employment creation. In addition, FDI flows have assisted the Lao economy in poverty alleviation. Laos has been learning to encourage FDI in order to support its economic reforms and achieving significant development. Over the past decade, FDI flows to Laos have gradually grown. The 1990s saw a remarkable increase in the world FDI as a result of liberalization of FDI regulations in most part of the world. Developing country governments were driven by the need to attract foreign investment by offering investment incentives and removing major obstacles to foreign investment.

\section{LEGISLATION OF HYDROPOWER PROJECT CONTRACTING IN LAOS}

\section{A. Trade Promotion Policies in Lao PDR}

Recognizing the role of external trade in the country's economic growth and poverty reduction efforts, the government facilitates exports and imports through several policies, such as the:

1) One-Stop Service Policy. On October 13, 2004, the MOIC enacted Order Number 962 (Implementing Decree Number 205/PM on the Establishment of One-Stop Service) in an effort to facilitate exports and imports. This policy directs all export and import related agencies in all provinces and the nation' s capital, Vientiane, to establish offices at all border checkpoints and to abolish export-import licenses (except for gold, copper, vehicles, vehicle spare parts, petroleum, gas, diamonds, and other prohibited goods requiring import licenses from the MOIC). A study conducted by NERI in 2008 showed that the implementation of the OneStop Service policy facilitates cross-border trade by reducing time and costs [9].

2) Border Trade Facilitation Policy. In 2001, the MOIC issued Instruction Number 948 on the Management of Border Trade. This policy aims to promote small-scale commercial production and exports as well as create jobs and incomegenerating activities for people living on the country's borders It also classifies border areas into two types: remote areas and non-remote areas. Remote areas have no access to, or have difficulty in accessing, domestic markets while non-remote areas have good access to domestic markets. People in remote areas can export and import all kinds of products necessary for production and consumption while those in non-remote areas can export all their products but import only the necessary production inputs. People living in non-remote areas have to buy consumer products from the domestic market [10].

3) Special Economic Zone and Border Trade Area Establishment Policy. To facilitate trade and promote investment, the government implements policies governing special economic zones (SEZs) and establishing border trade. To date, one SEZ and three border trade areas have already been established. Additional incentives and facilitating measures are necessary to attract more investment and trade in the border areas and SEZs. For example, investors at the SAVAN-SENO SEZ enjoy privileges such as exemption from turnover and utilization and minimum tax and other incentives. These incentives include: (a) tax exemption during the early stages of investment and tax reduction based on sector and condition; (b) dividend tax of only 5 percent, which is lower than the normal rate; (c) profit tax of 5 percent, which is also lower than the normal rate; (d) transferable deficit within five years; (e) exemption from import taxes on raw materials, construction materials, equipment, machinery, transport vehicles, spare parts, and semi-finished products and end products for use in or assembly at the SEZ; and (f) reduced minimum registration capital based on investment sector. Investors at the Lao-China border trade area also enjoy various incentives, including (a) exemption from taxes on profit and income for the first four years of operation and a 50 percent reduction in said taxes for an agreed period when the four years are up; (b) seven-year exemption from land taxes; and (c) 10 percent reduction in import tax. If investors use domestic raw materials in their production processes, the import tax levied on the final products coming from the border trade area into the Lao domestic market is reduced based on the percentage cost of the domestic raw materials used vis-a-vis the total production cost. For example, the import tax for an investor who uses domestic raw materials costing 30 percent of the total production cost will be reduced by 30 percent when the final products are imported into the domestic market.

\section{B. Commercial Laws and Regulations}

\section{1) Investment Law}

Laos has one of the most liberal investment regimes in the region. The GOL has taken steps to improve the investment climate in the country. The government promotes investment in all sectors throughout the country except in sensitive areas affecting national security, the environment, public health and national culture. The GOL has amended the constitution to provide incentives for various sectors and investment zones and has updated investment regulations. One of the key features of the new Investment Law is the decentralization of the management of foreign investment by allowing local authorities to attract investment to their regions. In addition, the revised law outlines the forms of acceptable foreign investment and the rights, benefits and obligations of each type of investment.

For most investors, the place to start is the MPI. The MPI is the one-stop decision-making body for private and public sector investment. It is composed of senior ministers from various government agencies. The Investment Promotion Department (IPD) is the MPI's operational arm for private sector investment. The IPD reviews investment applications and grants concessions to investors and investment projects meeting the requirements laid out in the Investment Law. Please note that for general business activities (i.e., not 
concession activities), the relevant government agency is the Ministry of Industry and Commercial [11].

\section{2) Contract and Tort Law}

Based on Articles 19 and 20 of Law on Contract and Tort No. 01/NA dated 8 December 2008 allow a contract to be nullified by an effected party if the contract found not to be beneficial to such party, or was made by necessity in exceptional circumstances, or if it conflicts with state of public interests.

Contracts governed by Lao PDR law should be notarized by the Notary Office, Ministry of Justice, and some contracts must also be registered, for example contracts creating a security must be registered to perfect the security.

The notarization of a contract confirms the validity and legality of a contract under Lao PDR laws and also ensures that if there is a dispute in relation to the contract, the contracting parties are limited to disputes over facts and/or performance [12].

\section{3) Labor \& Immigration}

The 2006 Labor Law, as amended in 2013, regulates employment and matters such as benefits and obligations in employment contracts. The law limits the proportion of foreign employees on a payroll. Foreign employees require visas and work permits.

Labor and immigration are critical issues in Lao PDR, being a relatively small population surrounded by larger countries with substantially larger and better- trained workforces. While a certain amount of foreign labor is welcomed by Lao PDR, its growing economy needs an increasing amount of skilled Lao workers that the country is not yet able to supply. According to a World Bank Group report, an "inadequately educated workforce" is the main obstacle to growth identified by Lao firms in 2012.

The 2013 Labor Law introduced collective labor contracts, which were not in the old 2006 law. A collective labor contract is a joint agreement between multiple employees or employee representatives and one or more employers in accordance with regulations and the law. They are the result of collective bargaining or documentation agreed upon for implementation according to the law. Collective labor agreements must be submitted to the Labor Administration Agency for examination, and must be registered or notarized by the court to ensure official use [13].

\section{4) Taxes}

Under the Tax Law, profit tax is payable by individuals, legal entities which belong to Lao citizens, foreigners, persons having no nationality who undertake production and business activities or work permanently or temporarily in Lao PDR, as well as those having residence or business premises in Lao PDR and go on a mission abroad which carry out activities that generate profit in Lao PDR. All companies that are registered under Lao law, or that are incorporated under foreign law and carry on business in Lao PDR, are subject to the Lao profit tax.

The Minimum Tax has been abolished. Previously the Minimum Tax was imposed on the revenues of all companies that either made profits below a certain level or made losses in a tax year. The practice under the Amended Tax Law is to calculate Profit Tax on an actual basis based on revenue less deductible expenses with no payment of minimum tax should the business report a loss. Most foreign investments and foreign investors will be affected by Profit Tax, Income Tax, Value Added Tax, Lump Sum Tax, Dividend Tax, Excise Tax, Environment Tax and various withholding taxes on Lao and foreign employees [14].

\section{5) Banking \& Finance}

After commencing economic reform towards a more liberalized system, the Lao Government tried to bring the banking and finance system in line with the demands of the economy. Its central bank is named the Bank of the Lao PDR (BOL), which has the mandate for regulating, supervising and issuing licenses to banks and other non-bank financial institutions (excluding insurance and securities) as well as monetary policy. The BOL supervises the operations of commercial banks and financial institutions and monitors the foreign exchange market to maintain financial stability [15].

Commercial banks are encouraged by the Government to invest and provide credit to support domestic and foreign investments in Lao PDR. Commercial banks may engage in all banking operations including receiving deposits with and without interest, extending credits and discounting of negotiable instruments, buying and selling foreign currencies, issuing cheques, payment cards and other means of payments. Commercial banks may also engage in financial business including issuing, buying and selling debt securities, financial leasing, distributing debt and equity securities, etc.

Consideration of banking licenses for individual and nonbank applicants has been temporarily suspended by the BOL since May 2014 in order to slow down the growth in the number of banks and focus its efforts on strengthening banks already in operation. The suspension will remain in effect through 2016 [16].

\section{6) Import \& Export}

In 2010 the Lao customs procedures were simplified and automated through the Automated Systems for Customs Data Management (ASYCUDA). Currently the system is installed and operating at eleven international border checkpoints and has helped reduce customs clearance delays and costs, as well as facilitating faster and more reliable international trade between Laos and other countries. The GOL has taken measures aimed at making it easier to trade across borders, including the introduction of new regulations limiting the government agencies that may be involved in inspecting goods at the border [17].

\section{7) Ownership of Land \& Property}

All land in Lao PDR is owned by the "national community" as part of the "national heritage." The GOL grants the use of land to Lao citizens, or may grant a concession over the land to foreigners via a concession agreement. "Ownership" of land in the Lao context is thus defined by the level of land use rights granted to the individual or company according to the Land Law and the contract existing between the parties. Lao citizens can acquire 
permanent land use rights, which includes land protection right, land use right, land usufruct right, right to transfer land use rights, and right to inherit land use rights. The maximum period of lease from the GOL to a Lao citizen is 30 years, which can be extended upon application. Foreign individuals or organizations may thus only hold land via lease from a Lao citizen or concession from the GOL, through which they are granted temporary land use rights. At present, two main types of land tenure exist: [1] Private land lease from Lao nationals: Leases from Lao citizens to foreign investors are limited to 20 years for developed land (land with buildings) or 30 years for non-developed land (vacant land). These periods may be extended upon agreement between the parties and approval from the provincial/city administration. [2] Concessions: Conditional leases granted by the GOL over state private land. The GOL, the National Land Management Authority and the Land Management Authority of the province/city, have the right to give state land on lease or concession to other persons or organizations, based on the scope of the organization's rights. Foreign investors may lease such land pursuant to the terms of a concession agreement entered into with the GOL [18].

Rights of land used for residential purpose: Investor will be granted rights on purchasing rights of land use for their residential purpose, if the following conditions are satisfied:

- Import of registered capital (in cash) at lease US\$ 500,000 .

- Must be government owned Land and designated by the government.

- Certificate on location of investment which is issued by local authority.

- Provide land use rights not than $800 \mathrm{~m} 2$ to build facilities for residential or business purpose.

- The government will allocate land to investors for duration consistent with the investment duration.

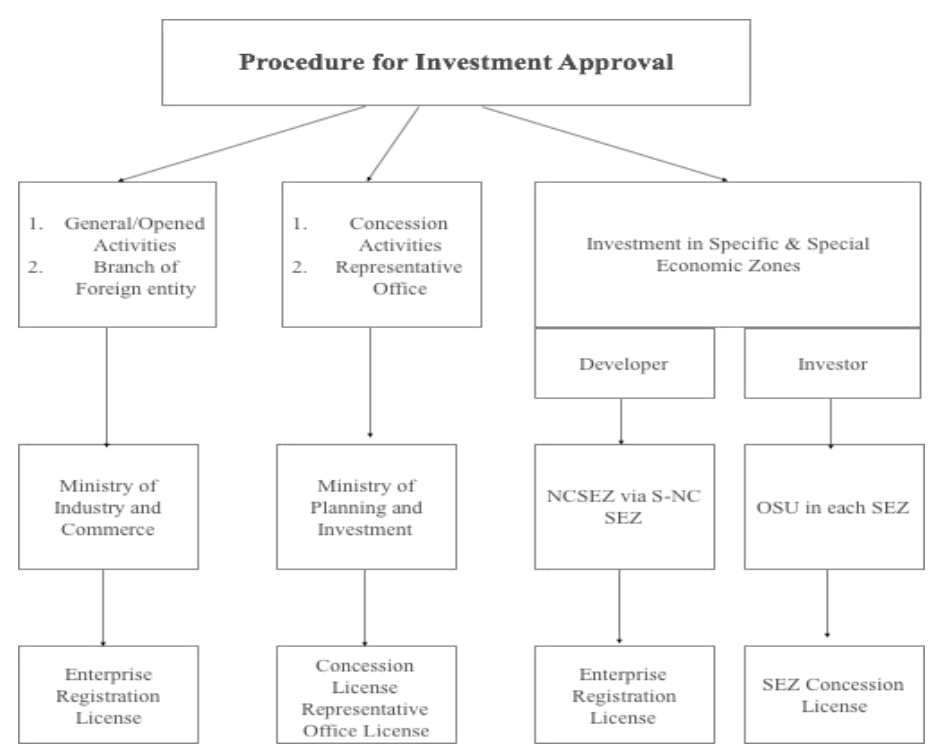

Fig. 1. Procedure for investment approval

\section{8) International treaties}

(MOIC 2012) Lao PDR actively pursues an open trade administration and the trade policy regime has been reformed to enhance transparency and secure an enabling trade environment. At the same time, the GoL has continually expanded its trade relations with countries around the world. To date, Lao PDR has broadened its trade relations with more than 50 countries, in which the main trading partners are Thailand, Vietnam, Australia, Korea, Malaysia, England, France, Germany, Japan, and the United States of America. It has concluded and signed trade-related agreements with 18 countries namely Argentina, Belarus, Bulgaria, Cambodia, China, Indonesia, India, Korea DPR, Kuwait, Malaysia, Mongolia, Myanmar, the Philippines, Russian Federation, Thailand, Turkey, the United States of America, and Vietnam.

Basic agreements concerning trade and investment have been established between China and Laos. In the year 1988, the two countries have signed trade agreement, and border trade agreement. In 1999, the agreement on avoidance of double taxation has been signed. In 1993, bilateral investment agreement has been made. And in 2004, in the 8th conference of China-ASEAN Leaders meeting, agreements about the goods trade and dispute resolution system have been made. And from 1990's to now, there are more than 15 agreements between two countries.

Lao PDR has market access opportunities under unilateral and reciprocal preferences from 47 developed and developing countries. As a LDC, Lao PDR is granted the unilateral tariff preferences under the Generalized System of Preferences (GSP) from 36 countries including the European Union (EU), Australia, Belarus, Canada, Japan, New Zealand, Norway, Russian Federation, Switzerland and Turkey. In 2002 the European Union granted a duty free quota free market access to LDCs under the everything, but Arms (EBA) initiative. Moreover, Lao PDR also obtains preferential tariff treatments from some emerging economies like China, R. Korea, Chinese-Taipei and India. These systems of preferences aim to help LDCs reduce poverty by stimulating their exports [19].

In addition, Lao PDR is granted unilateral preferential treatments by older ASEAN members: Thailand, Malaysia, the Philippines and Brunei Darussalam under ASEAN Integrated System of Preferences (AISP) scheme. The AISP scheme was adopted on 1stJanuary 2002 in order to implement the Initiatives for ASEAN Integration (IAI) for narrowing development gaps between established and newly joined ASEAN member countries. Under this scheme, these countries have granted preferential tariffs to CLMV (Cambodia, Lao PDR, Myanmar, and Vietnam) on a voluntary and bilateral basis. There are in total 1,117 tariff lines eligible for tariff preferences under this scheme. Indeed, only Malaysia, the Philippines, and Thailand have legally enacted the implementation of the AISP Scheme [20].

Apart from that, as one of the LDC Participating States of APTA, Lao PDR has also been granted unilateral preferential tariff treatment by China, R. Korea, India and Sri Lanka.

With respect to the reciprocal tariff treatments, Lao PDR is eligible to export to ASEAN countries under CEPT scheme. Under this scheme the import tariffs of the member states 
have significantly been reduced to $0 \%-5 \%$. Similarly, as a result of FTA negotiation with ASEAN dialogues partners, China, R. Korea, Japan, India, and Australia-New Zealand have scheduled tariff reductions in a reciprocal basis with Lao PDR. Further, under APTA, Lao PDR is eligible to export some products to China, R. Korea, India, Sri Lanka and Bangladesh with lower tariff rates.

Investment treaties contain investor-state dispute settlement (ISDS) provisions that the investor can use to lodge a claim against a state breaches of the protections provided in the treaty [21].

\section{Dispute Solution in Laos}

\section{1) Investment Risk Prevention in Laos}

The investors cannot operation without the risk so when the investors want to do business they can conduct a thorough due diligence covering: potential; laws and regulations affecting investment, contracts, industry specific laws; local practice; political risks; applicable investment treaties, draft contracts to take into account any gaps or peculiarities in the law. Other things, include detailed force majeure, termination and dispute resolution clauses, Consider taking out insurance to cover high level risks, for example political risk insurance and the most important to ensure your contracts any gaps or peculiarities in the Lao laws [22].

\section{2) Tools and technique of Dispute Resolution}

Recourse to the Lao court system by foreign and domestic investors to resolve commercial disputes is limited, and nonjudiciary methods of dispute settlement are the preferred option. While the arbitration system in Laos is in a state of development, an increasing number of commercial disputes are presently being submitted for resolution through mediation and [23].

The foreigner may file a case in a Lao court. The 2012 Law on Civil Procedure states specifically that it shall apply to foreigners who have disputes arising in the territory of Lao PDR. Moreover, the equality of foreigners before the courts will be recognized, without discrimination as to gender, race, ethnicity, socio- economic status, language, education level, occupation, belief, place of residence, among other things.

In practice, courts usually require foreign litigants to notify their respective embassies or consulates before filing cases in Laos.

Lao PDR recognizes and enforces the decisions of foreign courts. The decisions should first be translated into the Lao language. The courts will consider and decide whether or not to recognize said decisions based on the following criteria:

(1) The decisions are from countries that are members of international treaties to which Lao PDR is a party;

(2) Such decisions do not affect the sovereignty and do not contradict Lao laws; and

(3) Such decisions do not affect the peace and orderliness of Lao society.

The recognition of foreign arbitral awards shall be performed in the same manner as the recognition of the decisions of foreign courts.

The courts are currently not separated as in most civil law countries. As such, a commercial dispute will be heard in the court of the first instance or municipal court, which also tries criminal cases. A commercial court was established in 2003 and began work in 2005 (ECCIL). The 2012 Law on Civil Procedure provides for a Commercial Chamber, which has jurisdiction over cases involving partnership contracts, business and commercial contracts, or commercial documents, such as promissory notes, bills of exchange, cheques, commercial loan agreements, as well as bankruptcy and liquidation, export and import of goods, insurance, etc.

The Judicial system in Lao PDR consists of the People's Supreme Court, the People's Court of Appeal, the People's Court at Provincial and City level, the People's Court at District and Municipal Level, and the Military Court.

There are records of previous decisions. In Its adjudication, a Court must comply with the laws of Lao PDR. In the event that any matter is not determined by the laws or where the law is silent on any facts or issue, the Court must take into account the precedents or previous decisions of the higher courts.

Foreign investors in Lao PDR have the right of recourse to arbitration and mediation. The 2010 Law on the Resolution of Economic Disputes provides for the Center and Offices of Economic Dispute Resolution (OEDR) to manage and govern disputes resolution through arbitration and mediation. Foreign investors, however, do not yet consider it a viable system, as OEDR arbitrators and mediators are not adequately trained for complicated international commercial disputes.

Lao PDR is a member of the Convention on the Recognition and Enforcement of Foreign Arbitral Award (New York Convention 1958), which was countersigned on 17 June 1998 and was put into effect on 15 September 1998. Thus, Lao PDR should recognize and implement a foreign arbitral award [24].

Many foreign investors routinely include a clause in their contracts allowing recourse to international arbitration in places such as Singapore and Hong Kong.

Foreign arbitration is valid and binding under the laws of Lao PDR. As provided in the 2012 Law on Civil Procedure, the recognition of foreign arbitral awards shall be performed in the same manner as the recognition of the decisions of foreign courts [25].

\section{LAWS OF HYDROPOWER PROJECT IN LAOS}

\section{A. The Procedure of Approval in Hydropower Project}

According to the investment law in the year of 2004, the outlines an application and approval process for FDI in hydropower sector [26]. This process is the responsibility of the Ministry of Planning and Investment (MPI), and the decisive decision on project approval is the Prime Minister's Office (PMO). The Environment Impact Assessment (EIA) and Strategic Impact Assessment (SIA) are to be carried out as one of the last steps in the approvals process. Implementing EIA and SIA are the responsibility of the investor, and are 
reviewed by the relevant Lao technical ministries such as: Ministry of Energy and Mines (MEM), Water Resource and Environment Agency (WREA, PMO), and Ministry of Agriculture and Forestry (MAF).

The Independent Power Producer (IPP) has to submit Application of Study Plan (AOSP) to MEM after the plan review successfully pass, the IPP should sign the Minutes of Understanding (MOU) with the government of Lao PDR.

Submit application of Feasibility of Study (AOFS) and IEA to MPI and MEM.

The new investment law (2009) was introduced by the government of Lao PDR in the year of 2009; with add more policies on income tax to investors who investing in three zones and the zones were divided each zone into three different layers, which was highlighting some new features as below:

Harmonized the domestic investment law and foreign investment law;

\section{Shorten procedures to open a new business}

No terms of investment;

Foreign investors have rights to exercise the lands and properties;

Investment incentives: Education and Health care sectors are top priorities;

Pro-active Investment promotion agency (IPA): investment calling lists;

Providing better facilitation from IPA: One Stop Shop services

In conclusion, the investment incentives which provided by the government of Lao PDR under the Investment Promotion Law in the year of 2009, by offering profit tax and other incentives to foreign investment enterprises. Commonly the exemptions on profit tax and concessional tax rates are dependent to the type of investment and the geographical location of investment. Moreover the procedure for the establishment and approval process of foreign investment enterprises had been shortening by the Investment Promotion Law.

\section{B. Proposed fiscal regime for hydropower concessions}

Experience in other countries reveals that governments have had difficulty in setting tax levels for resource projects and particularly in finding the right balance in seeking rents from developers, i.e. neither to under tax so as to sacrifice rents that might be reasonably expected or overtax which may deter investment. After primary taxes such as corporate income tax have been deducted, governments ultimately need to develop a mechanism that calculates and efficiently transfers economic rents from projects, ideally based on profit rather than production. As part of the 2009 Lao PDR Country Development Report, a study (Mac George et al., 2010) was commissioned on the fiscal regime for hydropower concessions that recommended the following for the Government of Lao PDR's consideration:
Ministry of Energy and Mines, supported by the Ministry of Finance, to issue a clear policy statement defining the standard method for determining fiscal benefits for exportoriented hydropower project to ensure developers are fully aware of the Government's expectations before project agreements are negotiated [27].

The business turnover tax, excise taxes, profit taxes and corporate income tax to be the primary taxation of hydropower projects. These taxes may be reduced in accordance with the Law on the Promotion of Foreign Investment, but no project specific dispensations should be made.

Secondary taxes, such as the existing royalty arrangements, to continue to apply to extract economic rents (i.e. the value of production after deductions for operating and capital costs), but the GOL should consider moving to a resource rent tax system. GOL should consider abandoning the specific ad valorem royalty tax under consideration, i.e. the USD $0.65 \mathrm{c} / \mathrm{kWh}$ which would be levied regardless of the economic rents generated by the project projects.

Alongside primary and secondary taxes, other approved sources of fiscal benefit could include: (a) an upfront concession fee; (b) dividends from investments in IPPs as specified by a GOL IPP investment policy; and (c) minimal use of a discounted electricity sales specified under a discounted electricity policy. These other sources of fiscal benefit, however, do not contribute markedly to economic rents, so their rational must depend on other criteria.

Based on literature review of legal risk management of hydropower project contracting in Laos has not many results concerning about the legal risk management of hydropower project contracting and most of study from the international organizations and other official reports.

The Sinohydro Corporation, the largest hydropower dam building company in China, is developing numerous hydropower projects in both Laos and Cambodia. And the China Southern Power Grid Co. Ltd. is either active or exploring opportunities in all three countries. In spite of its high potential, hydropower has remained largely untapped. However, in Laos and Cambodia, China is involved in roughly 21 hydropower projects either as an investor or developer. Most of the Chinese projects are designed and implemented by Chinese companies and backed by the China Exim Bank and Sinosure, which are involved in the majority of China's overseas investments [28]. Based on Mekong River Committee (MRC) researched about specific tasks of the hydropower risk management and mitigation specialist include: Collaborate with the ISH0306 Consultants Team to produce "Guidelines for Hydropower Impact Mitigation and Risk Management in the Lower Mekong Mainstream and Tributaries"; Coordinate with the Team Leader of ISH0306 and the communication with MRC Programmes; Assist the Team Leader of ISH0306 in the preparatory work of the various reports in each implementation phase of ISH0306; Assist the ISH0306 Consultants Team in the process for Data and Information collection; Assist the ISH0306 Consultants Team in the completion of ISH0306 Development of Guidelines for Hydropower Impact Mitigation and Risk 
Management; Contribute input to an update of the "Preliminary Design Guidelines" on mainstream and significant tributary dams; Help Implement an awareness and capacity-building programme to disseminate an understanding of the mitigation options amongst key stakeholders in the region; Collaborate with ISH Team members to help the Mekong Countries to strengthen the capacities of their members/officers for a sound understanding and appreciation of socio-economic issues and ecological complexities as the basis for sustainable hydropower development aiming at increasing awareness regarding SHD at all levels of decision making; enhance knowledge and skills at academic and research institutions and share experience on good practices from the region and worldwide with regard to planning, construction and operation of hydropower projects and associated reservoirs and dams promote the application in academic and research institutions and to provide professional training for planners and managers to cope with the challenges of SHD; Additional related duties as requested by the ISH Programme Coordinator.

Based on Department of Energy Promotion and Development of Ministry of Energy and Mines in Laos researched about operational of Hydropower Project in Lao PDR as following: Analyzing Incentives and Disincentives on FDI in Hydropower Sector. Lao PDR is considered as landlocked country which situated in Southeast Asia region and shares border with five countries: Myanmar, Cambodia, China, Thailand and Viet Nam. However the government of Lao PDR is converting the landlocked to land-linked by connected the main roads to the every international border pointed. Thus Lao PDR geographically is going to be trade hub in this region and huge market which providing access to ASEAN market plus connecting to the southern part of China which attracting FDI in numerous sectors. Moreover there is investment incentive in hydropower sector, due to the increasing demand on electricity from countries such as Thailand, Vietnam and china, which providing great opportunity to Lao PDR for exporting electricity to those neighbors.

Government of Lao PDR is continuing in enjoyment to receiving the request from foreign investors for the concession of the development in hydropower and mining. With the abundant in mineral and water resources, thus these two sectors are largely attracting FDI into Lao PDR. The abundant in water resources lend a hand for Lao PDR to receive more FDI in the hydropower project, which lead Lao PDR to be major electricity export-oriented in Southeast Asia region. Furthermore, unexploited mining areas, which have plenty of mines such as: gold, copper, Zink, tin and coal are attracting numerous foreign investors around the world.

Social and political stability is another major reason that encourages the foreign investors for trustworthy invest or doing business in Lao PDR. With a very near to the ground of crime rate, no noticeable ethnic conflicts, no political issues and very peaceful country Thus it comes into view to be very low risk for short term and long term investment

The investment incentives which provided by the government of Lao PDR under the Investment Promotion
Law in the year of 2009, by offering profit tax and other incentives to foreign investment enterprises. Commonly the exemptions on profit tax and concessional tax rates are dependent to the type of investment and the geographical location of investment. Moreover the procedure for the establishment and approval process of foreign investment enterprises had been shortening by the Investment Promotion Law.

Inexpensive labor and land: By comparing with the neighboring countries of Lao PDR, the cost of labor and land are much cheaper, which regard as one of the attractiveness for investment in Lao PDR. Especially the land leasing policy which offered low rate in rental fee and longer investment term which up to seventy-five years. On the other hand the weak point of Lao PDR is the quality of labor which mostly amateurish labor, even though the cost of labor in Lao PDR is cheaper comparing to its neighboring countries.

IEEJ (August 2012) Major difficulties and bottlenecks currently faced in formulating energy policies such as: Lack of an integrated national energy policy, lack of data and information of all sub- sectors of energy, The limitation of manpower, Mandate among agencies are not clearly described and coordinated [29].

NORPLAN, (2004) Legal and Administrative Setting and the Implementation of Environmental and Social Safeguard Measures.

The Environmental Protection Law (1999) is the most important piece of environ- mental legislation in the country. It was further elaborated by an implementation decree in 2002 A general framework entitled "Regulation on Environmental Assessment in Lao PDR" was issued in 2000. Based on this regulation the Department of Electricity of Ministry of Industry and Handicraft (MIH) developed and is- sued their own environmental and social assessment regulations in the period 2001 - 2003. These regulations are broadly consistent with international safe- guard regulations and guidelines [30].

The environmental and social safeguard institutions responsible for the hydro- power sector at central level are the Social and Environmental Management Division (SEMD) of the Department of Electricity in MIH and the Department of Environment under the Science, Technology and Environment Agency (STEA). Of these two, STEA, through the provisions in the Environmental Protection Law, has an overall responsibility for the environmental safeguard system and thus the duty to oversee all issues in relevant sector ministries, including MIH. The Social and Environmental Management Division in MIH is more directly involved in the supervision of the different EA processes. The Division is involved at an early stage in determining the level of assessment needed, in the development of ToRs for Initial Environmental Evaluation and in review and approval of the various EA and EIA documents.

IFC (2011) Yet, if hydropower continues to develop at a rapid pace under existing regulatory conditions, the developments may cause adverse and irreversible damage on the environment and local people's livelihoods [31]. Therefore, there is a pressing need to improve environmental 
and social standards as well as improve the skills and capacity of the hydropower sector as a whole.

MIGA member of world bank (2006) Risk mitigation: Guarantees against political risks were essential to provide the international dollar lenders with the level of comfort that they needed to support the NT2 project. For a project of this size, the recourse to multi- lateral agencies offered the only practical solution [32]. Besides being concerned about the traditional political risks of currency transfer restriction and inconvertibility, expropriation, and war and civil disturbance, the lenders were also interested in protecting their rights under the numerous project agreements with the government of Lao PDR and EGAT. With the support of the government of Lao, the World Bank and MIGA mitigated specific political risks under the project agreements in the country. In addition, MIGA also covered other political risks in both countries, Lao PDR and Thailand, through a stand- alone coverage. Under its breach of contract coverage, MIGA covered selected contractual obligations of the government of Lao contained in the concession agreement between NTPC and the government with respect to its payment obligations to both NTPC and the lenders as a result of the termination of the agreement, as well as obligations under the direct agreement with commercial lenders, with respect to the government's recognition of the lenders' third party rights under the concession agreement, including subrogation rights in the event of default. In addition, MIGA's policy covered commercial lenders' rights in case of termination of the power purchase agreement (PPA) between EGAT and NTPC as well as EGAT's obligations under the Form of Acknowledgement and Consent and the subordination agreement.

MIGA will pay compensation to the lenders should the following events occur: There is a default on covered loans as direct result of a breach by the government of Lao or EGAT of the selected contractual obligations under the project agreements; A final and binding arbitration award is rendered to the lenders for a breach by the government of Lao or by EGAT of their contractual obligations under the project agreements; and Lenders are unable to enforce the award against the relevant government within a specified waiting period.

ICPDR (2015) Environmental protection and biodiversity conservation issues for instance: Negative impacts of hydropower generation have led to rather negative reception of new projects by civil society and financial institutions assess impacts in detail, Economic, social and environmental benefits can be maximized in case all benefits and impacts are considered from the very beginning, Significant investments needed to remediate negative impacts of existing facilities to meet requirements of EU environmental legislation - costs (much) higher compared to initial consideration, Legal compliance with existing legislation, i.e. WFD and N2000 [33].

As the government of Lao PDR set the economic outlook in the year 2020, its vision to the year 2020 is to graduate from the status of being a least developed country and become a sustainable development nation. To achieve such goal of National Development Vision to the year 2020, Lao PDR needs more capitals, technology, and capable human resource, as the Government of Lao PDR lack of these things. Thus, the FDI especially in Mega projects such as hydropower sector and mining sector are the significant contributors for increasing the government's revenue, creating jobs, introducing new market and business system [34].

\section{CONCLUSIONS}

As the Laos has been becoming more and more open to foreign direct investment, amendments and new laws and regulations of incentive to investment are in expectation. Because of cultural and historical reasons, there are still some hindering factors for foreign investment in Laos currently. Contractors and subcontractors are both exposed to risk within a project. As such, it is equally important to both parties to complete a formal risk assessment. Understanding the risks involved and managing risk response through standard response types such as mitigation and added contingency further ensure project success [35]. However, it's a fine line between applying too much contingency or risk mitigation and not implementing a risk response at all. But with the correct methodologies and tools in place such as Oracle's Primavera Risk Analysis the odds of establishing a win-win relationship between the contractor and the subcontractor go up significantly.

The management of risks requires establishing and nurturing a culture of risk management. In such an environment, project teams work together through each phase of project delivery to manage risks. The intent is to bring focus to the understanding that the project teams are not only designing roads, bridges, drainage systems, etc., but are developing plans, specifications, and estimates for construction contracts. Project risk management is everyone's responsibility, and there are accountability check points to ensure that project risks are being managed [36].

The selection of the contracting strategy reflects the desired risk allocation and the objective and purpose that the project owner wants to achieve [37]. Therefore, the specific features and factors of the project have to be analyzed and compared with the characteristics of the respective strategy in order to decide which solution is the most appropriate. It is should be noted that the paper still has some limitations. Though, firstly, the article concludes ten key risk factors, that does not mean the other factor should be ignored, and concrete analysis should be carried out according to the specific situation in project practices. Secondly, the article focuses on analysis for the key risks and sharing situations for international hydropower projects only, and this may not be applicable for other types of international projects, therefore, specific analysis shall be performed in accordance with concrete situation accordingly. Lastly, for international hydropower projects, this paper holds the point that follow-up studies on the concrete preventative strategies for specific risk, the specific risk proportion between owners and contractors should be further analyzed and discussed [38]. (Li Wei, Kang Haigui, Song Jinbo 2012).

From the interview discussions, several recommendations are suggested to reduce possible risks and to improve the 
situations if risks are encountered for marine projects:

To provide an early planning at the initial project stage in examining possible risks may be encountered;

undertake risk assessment at the initial project stage in $\mathrm{pr}$

To voiding comprehensive methods to solve different risk situations;

To employ experienced employees for the projects;

To provide training and development programs to the employees;

To collect up-to-date information before project starts; and

To communicate with other project parties by regular meetings for ensuring the project progressing well.

To find a good consultants and expert lawyers for preparing the project contracting and to work on contract administration [39].

\section{REFERENCES}

[1] “Investment Policy Effect on FDI in Hydropower Sector,"2015.

[2] "Bilateral Investment Agreements," 2012.

[3] Kaygusuz, 2004.

[4] Beijing, China, "Opportunities and Challenges for Chinese Companies in Overseas Investment," 2013.

[5] Xinhua News Agency "Chinese companies helping Laos eradicate poverty in remote," 2015.

[6] KPL, "China - Second largest investor in Laos".

[7] "Law on Investment Promotion," Vientiane Capital, Laos, August 2009.

[8] Runckel \& Associates, FDI, 2015.

[9] Order Number 962, Implementing Decree Number 205/PM on the Establishment of One-Stop Service, 2004.

[10] MOIC issued Instruction Number 948 on the Management of Border Trade 2001

[11] Law on Investment Promotion, Vientiane Capital, Laos, August 2009.

[12] Articles 19 and 20 of Law on Contract and Tort No. 01/NA dated 8 December 2008

[13] Law on Labor (Amended Version), NA Vientiane Capital, Laos, 24 December 2013
[14] Law on Taxation, No. 04/NA 19, May2005.

[15] Law on The Bank of The Lao People's Democratic Republic, October 1995.

[16] Sciaroni \& Associates Sole Ltd Co., in Laos, Booklet of Doing Business in Laos, 2015.

[17] MOIC "Guide to Import and Export," 2012.

[18] Law on Land, NA, 2003

[19] Market access for Lao PDR, 2012.

[20] MOIC (2012), Bilateral trade Source.

[21] R.S. Consulting Group, "BREAKING GROUND: Chinese Investment in U.S. Real Estate," 2016.

[22] W. Li, H. Kang and J. Song, "A Study on Risk Allocation for International Hydropower General Contracting Projects," 2012.

[23] T. Rao and S. Tobias, "Assessing and managing risks using the Supply Chain Risk Management Process (SCRMP)," Supply Chain Management: An International Journal, vol. 16, 2011, pp. 474 - 483.

[24] Convention on the Recognition and Enforcement of Foreign Arbitral Award (New York Convention 1958)

[25] Law on Civil Procedure, 2012.

[26] Department of Energy (DOE) (2012), Contract Management Planning, source available at: www.poweringprogress.org

[27] Institutional Structure of Lao PDR's Power Sector (2009), Source available at: www.poweringprogress.org

[28] P. SINGHALATH, 2012.

[29] IEEJ, Major difficulties and bottlenecks currently faced in formulating energy policies, August 2012.

[30] “The Environmental Protection Law," 1999.

[31] IFC (2011) Yet.

[32] MIGA member of world bank, "Risk mitigation," 2006

[33] ICPDR, Environmental protection and biodiversity conservation issues, 2015.

[34] J. Sari, "Challenges in developing sustainable hydropower in Lao PDR,” 2014.

[35] K. Prasanta, S. Dey and O. Ogunlana, "Selection and application of risk management tools and techniques for build- operate-transfer projects," vol. 104, 2004, pp. $334-346$.

[36] A.M. Ahmed, B.M. Kayis and S.T. Amornsawadwatana, "A review of techniques for risk management in projects" 2007, pp. $22-36$.

[37] S.R. Carolin, M. Alexander, and W. Gerhard, "Contracting strategies in the oil and gas industry," 2010.

[38] W. Li, H.G. Kang, and J.B. Song, 2012.

[39] Arion Legal, and Law Firm, "Investment Risk Preventation in Lao PDR". 